\title{
Highly Soluble Monoamino-Substituted Perylene Tetracarboxylic Dianhydrides: Synthesis, Optical and Electrochemical Properties
}

\author{
Kew-Yu Chen * and Che-Wei Chang \\ Department of Chemical Engineering, Feng Chia University, Taichung 40724, Taiwan; \\ E-Mail:m0111617@fcu.edu.tw \\ * Author to whom correspondence should be addressed; E-Mail: kyuchen@fcu.edu.tw; \\ Tel.: +886-4-2451-7250 (ext. 3683); Fax: +886-4-2451-0890.
}

External Editor: Dennis N. Kevill

Received: 8 November 2014; in revised form: 21 November 2014 / Accepted: 1 December 2014 / Published: 8 December 2014

\begin{abstract}
Three dialkylamino-substituted perylene tetracarboxylic dianhydrides with different $n$-alkyl chain lengths ( $n=6,12$ or 18), 1a-1c, were synthesized under mild conditions in high yields and were characterized by ${ }^{1} \mathrm{H} \mathrm{NMR},{ }^{13} \mathrm{C} \mathrm{NMR}$ and high resolution mass spectroscopy. Their optical and electrochemical properties were measured using UV-Vis and emission spectroscopic techniques, as well as cyclic voltammetry (CV). This is the first time that the structures and the properties of monoamino-substituted perylene tetracarboxylic dianhydrides have been reported. These molecules show a deep green color in both solution and the solid state and are soluble in most organic solvents. They all show a unique charge transfer emission in the near-infrared region, and the associated peaks exhibit solvatochromism. The dipole moments of the compounds have been estimated using the Lippert-Mataga equation, and upon excitation, they show slightly larger dipole moment changes than those of corresponding perylene diimides, 2a-2c. Additionally, Compounds 1a-1c undergo two quasi-reversible one-electron oxidations and two quasi-reversible one-electron reductions in dichloromethane at modest potentials. Complementary density functional theory calculations performed on these chromophores are reported in order to gain more insight into their molecular structures and optical properties.
\end{abstract}


Keywords: perylene tetracarboxylic dianhydrides; perylene diimides; intramolecular charge transfer; solvatochromism; Lippert-Mataga equation; density functional theory calculations

\section{Introduction}

Perylene diimides (PDIs) and perylene tetracarboxylic dianhydrides (PTCDs) have received considerable attention due to their potential applications in molecular electronic and optical devices, such as LCD color filters [1,2], molecular wires [3,4], photochromic materials [5,6], organic field-effect transistors (OFETs) [7-12], organic light-emitting diodes (OLEDs) [13-17], light-harvesting arrays [18,19] and organic solar cells (OSCs) [20-29]. Moreover, PDIs have been utilized as building blocks to construct supramolecular or artificial photosynthetic systems [30-33]. These organic molecules are advantageous due to their high molar absorptivities, excellent thermal and optical stabilities, reversible redox properties, high photoluminescence quantum yields and self-assembly behaviors [34-48]. The electronic characteristics of PDIs and PTCDs can also be fine-tuned by the substitution of a conjugated perylene core. Consequently, more and more PDIs and PTCDs with either electron-donating or electron-withdrawing groups have been reported in the literature [49-63].

PDIs and PTCDs suffer from serious problems, such as poor solubility and aggregation. A number of synthetic methods to prepare PDI and PTCD derivatives with improved solubility have been reported [53,55,59]. The synthesis of highly soluble PDI and PTCD derivatives is very important for process ability and for the preparation of their thin films to be used in optoelectronics applications, such as OFETs, OLEDs and OSCs. Soluble PDI derivatives can be obtained by introducing long and bulky substituents at the perylene core and/or at the imide nitrogen atoms, while soluble PTCDs can only be prepared by introducing substituents at the perylene core. Several diamino-substituted PTCDs based on this concept have been synthesized and studied so far $[64,65]$. However, to the best of our knowledge, the molecular structures, as well as the optical and electrochemical properties of monoamino-substituted PTCDs have not been reported yet. To expand the scope of highly soluble PTCD-based chromophores available for designing systems for colorful dyes and charge transport, we report here the detailed synthesis and characterization of monoamino-substituted PTCDs (1a-1c), shown in Scheme 1. Furthermore, the optical, electrochemical and complementary density functional theory calculations of the newly synthesized PTCDs are investigated.

\section{Results and Discussion}

\subsection{Synthesis}

Scheme 1 depicts the chemical structures and synthetic routes of monoamino-substituted asymmetrical PTCDs (1a-1c). In brief, the synthesis of 1a-1c started from an imidization of perylene dianhydride $\mathbf{6}$ and cyclohexylamine in the presence of acetic acid, followed by the mononitration of perylene diimide $\mathbf{5}$, giving a nitro compound 4 . The reduction of 1-nitroperylene diimide (4) by tin (II) chloride dihydrate $\left(\mathrm{SnCl}_{2} \cdot 2 \mathrm{H}_{2} \mathrm{O}\right)$ in refluxing THF afforded 1-aminoperylene diimide (3). Next, three highly soluble PDI derivatives (2a-2c) with different $N$-alkyl chain lengths $(n=6,12$ or 18$)$ were prepared by the alkylation 
of $\mathbf{3}$ with the corresponding alkyl halides. Finally, alkylamino-substituted PDIs 2a-2c were converted to the respective PTCDs via saponification to afford 1a-1c. The asymmetric structure of $\mathbf{1 a}-\mathbf{1 c}$ can be verified by the presence of seven signals (one singlet and six doublet signals) at $\delta 8.3-9.4 \mathrm{ppm}$ in the ${ }^{1} \mathrm{H}$ NMR spectrum (Figure 1), which indicates that there are seven different kinds of protons in the perylene core. Detailed synthetic procedures and product characterization are provided in the Experimental Section and Supplementary Materials (Figures S1-S10).

Scheme 1. The synthetic routes for $\mathbf{1 a - 1 c}$.

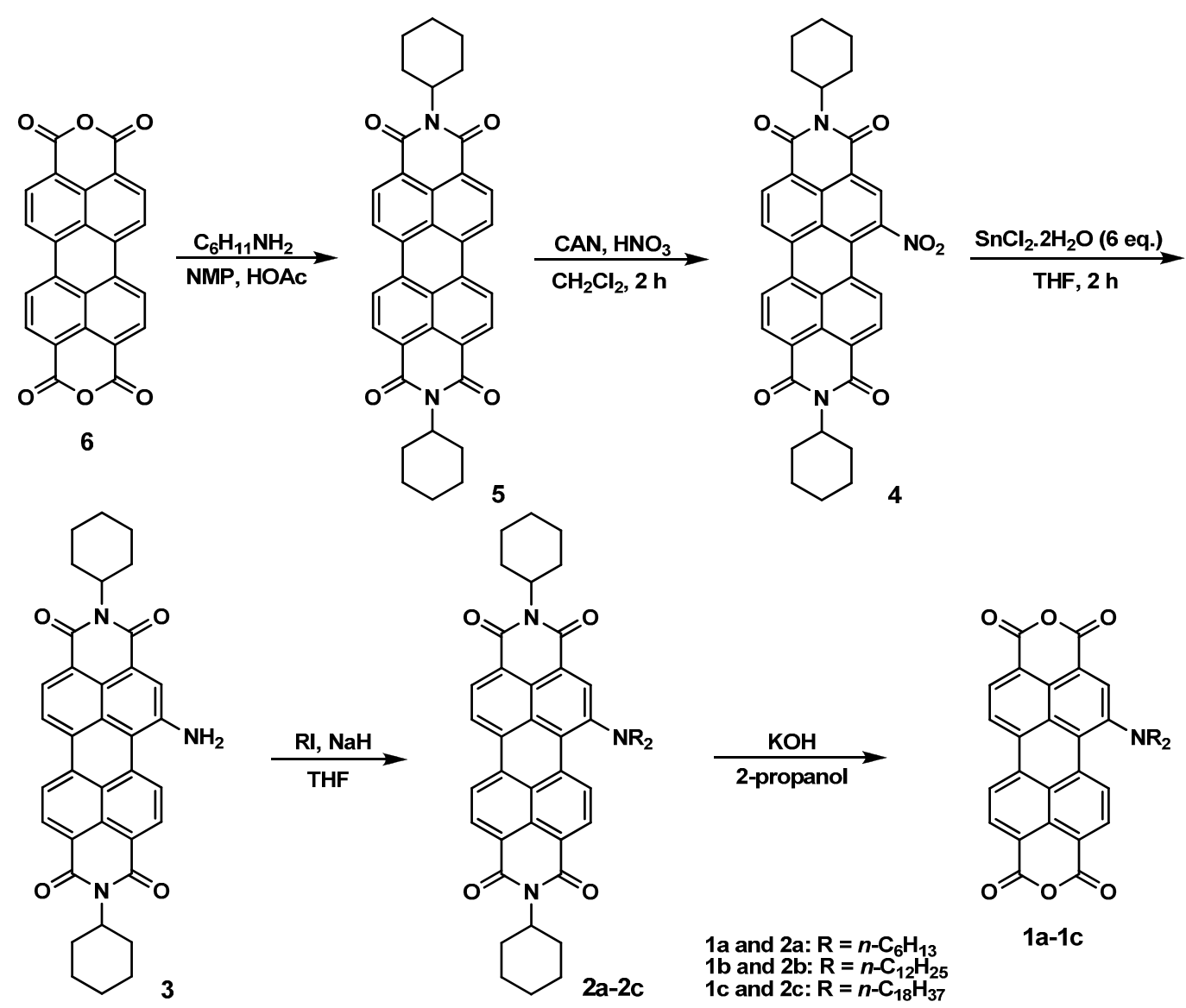

\subsection{X-ray Structure}

The structure of 2a was further confirmed by single-crystal X-ray diffraction analysis (Figure 2). To the best of our knowledge, this is the first time that the X-ray structure of monosubstituted PDI has been resolved. Compound 2a crystallizes in the triclinic space group $P$-1, with $a=9.8924$ (6), $b=14.6338(10), c=15.6221(10) \AA, \alpha=105.098(3)^{\circ}, \beta=103.386(2)^{\circ}, \gamma=107.772(3)^{\circ}$ and $Z=2$. The central six-membered ring of $\mathbf{2 a}$ is twisted with dihedral angles of $11.6(3)^{\circ}$ and $14.9(3)^{\circ}$ associated with bay area carbon atoms $\mathrm{C} 7-\mathrm{C} 8-\mathrm{C} 15-\mathrm{C} 16$ and $\mathrm{C} 11-\mathrm{C} 10-\mathrm{C} 13-\mathrm{C} 22$, respectively, these values being smaller than those of disubstituted and tetrasubstituted PDIs [39,60]. All $\mathrm{C}-\mathrm{C}$ bond lengths of the perylene moiety range between 1.358 and $1.486 \AA$ (Table 1), which indicates the presence of $\pi$-conjugation for all $\mathrm{C}-\mathrm{C}$ bonds. The longest bonds in the perylene backbone are the C8-C15 and C10-C13 bonds that connect the two naphthalene rings at a distance of $1.47 \AA$. The bond 
length is almost identical to the lengths observed for other PDIs $[39,60]$. These results demonstrate that the degree of conjugation of the perylene unit is similar in both unsubstituted and core-substituted PDIs.

Figure 1. ${ }^{1} \mathrm{H} \mathrm{NMR}\left(400 \mathrm{MHz}, \mathrm{CDCl}_{3}\right)$ spectra of $\mathbf{1 a}$.

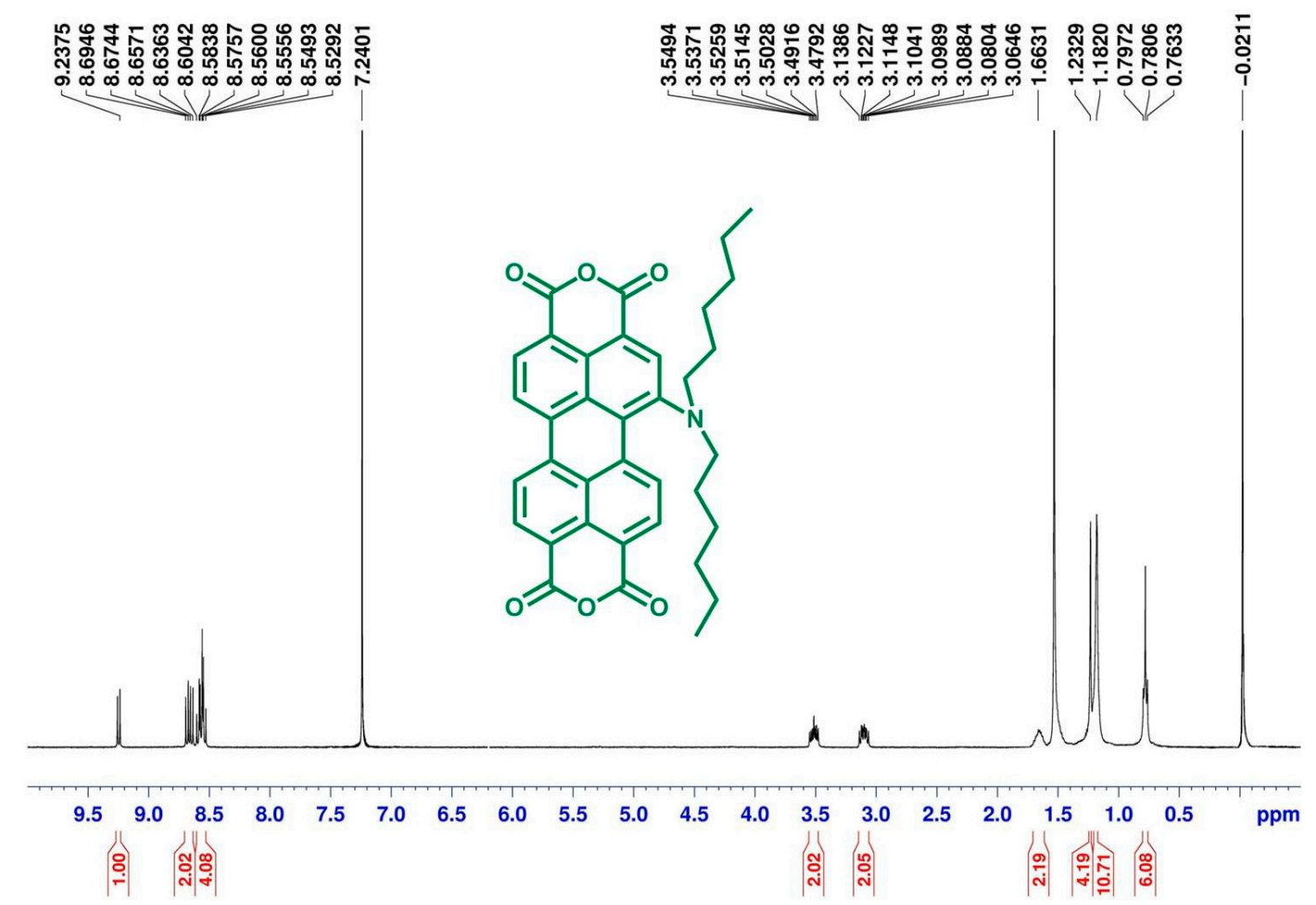

Figure 2. Molecular structure of 2a (left) and the view along the $\mathrm{N}-\mathrm{N}$ axis showing the twisted perylene backbone (right) (alkyl groups at imide nitrogen atoms and all hydrogen atoms are omitted for clarity). Displacement ellipsoids are drawn at the 50\% probability level.
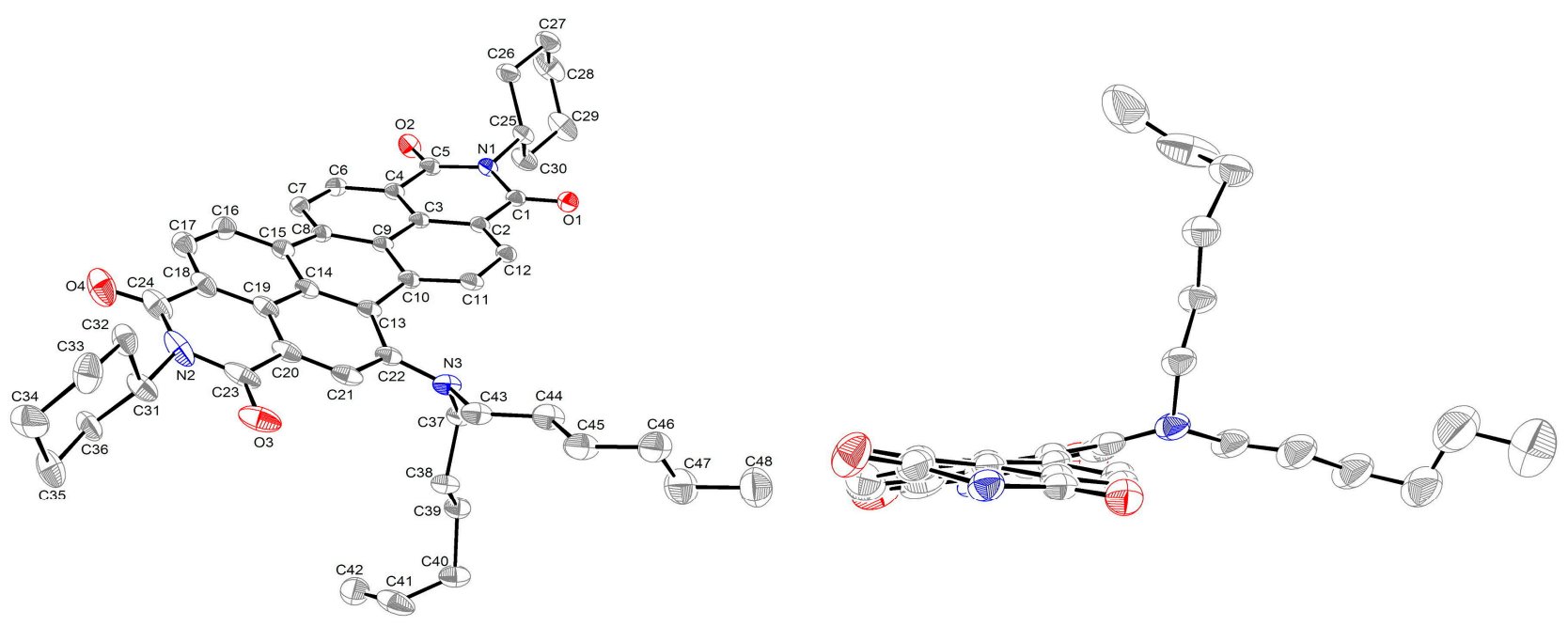
Table 1. Comparison of the experimental and optimized geometric parameters of $\mathbf{2 a}\left(\AA\right.$ and $\left.{ }^{\circ}\right)$.

\begin{tabular}{ccc}
\hline Compound 2a & X-ray & DFT \\
\hline Bond lengths & $(\AA)$ & $(\AA)$ \\
\hline $\mathrm{C}(1)-\mathrm{O}(1)$ & $1.220(3)$ & 1.227 \\
$\mathrm{C}(1)-\mathrm{N}(1)$ & $1.403(3)$ & 1.403 \\
$\mathrm{C}(1)-\mathrm{C}(2)$ & $1.469(3)$ & 1.481 \\
$\mathrm{C}(3)-\mathrm{C}(4)$ & $1.414(3)$ & 1.414 \\
$\mathrm{C}(6)-\mathrm{C}(7)$ & $1.388(3)$ & 1.397 \\
$\mathrm{C}(8)-\mathrm{C}(9)$ & $1.414(3)$ & 1.427 \\
$\mathrm{C}(8)-\mathrm{C}(15)$ & $1.464(3)$ & 1.464 \\
$\mathrm{C}(10)-\mathrm{C}(13)$ & $1.475(3)$ & 1.477 \\
$\mathrm{C}(14)-\mathrm{C}(19)$ & $1.427(3)$ & 1.429 \\
$\mathrm{C}(20)-\mathrm{C}(21)$ & $1.358(4)$ & 1.366 \\
$\mathrm{C}(20)-\mathrm{C}(23)$ & $1.486(4)$ & 1.487 \\
\hline $\mathrm{Bond}$ angles & $\left({ }^{\circ}\right)$ & $\left({ }^{\circ}\right)$ \\
\hline $\mathrm{O}(1)-\mathrm{C}(1)-\mathrm{C}(2)$ & $122.0(2)$ & 121.2 \\
$\mathrm{C}(2)-\mathrm{C}(3)-\mathrm{C}(4)$ & $119.3(2)$ & 119.2 \\
$\mathrm{C}(11)-\mathrm{C}(10)-\mathrm{C}(13)$ & $123.4(2)$ & 123.3 \\
$\mathrm{C}(13)-\mathrm{C}(14)-\mathrm{C}(19)$ & $120.6(2)$ & 120.4 \\
$\mathrm{C}(23)-\mathrm{N}(2)-\mathrm{C}(24)$ & $123.8(3)$ & 123.5 \\
$\mathrm{C}(22)-\mathrm{N}(3)-\mathrm{C}(37)$ & $116.8(2)$ & 115.8 \\
\hline $\mathrm{T}(3 r \operatorname{sion}$ angles & $\left({ }^{\circ}\right)$ & 9.4 \\
\hline $\mathrm{C}(7)-\mathrm{C}(8)-\mathrm{C}(15)-\mathrm{C}(16)$ & $11.6(3)$ & 13.4 \\
$\mathrm{C}(11)-\mathrm{C}(10)-\mathrm{C}(13)-\mathrm{C}(22)$ & $14.9(3)$ & 0.7 \\
$\mathrm{O}(1)-\mathrm{C}(1)-\mathrm{C}(2)-\mathrm{C}(12)$ & $3.4(4)$ & \\
$\mathrm{C}(19)-\mathrm{C}(14)-\mathrm{C}(15)-\mathrm{C}(16)$ & $3.0(4)$ & \\
\hline & & \\
\hline & & \\
\hline
\end{tabular}

\subsection{Optical Properties}

Figure 3 shows the absorption spectra of the green dyes 1a and $\mathbf{2 a}$, the purple dye $\mathbf{3}$ and the red dye 4 in dichloromethane. The absorption spectrum of 1-nitroperylene diimide (4) is almost identical with the spectrum of the non-substituted perylene diimide (5), but it does not show fluorescence [61]. On the other hand, the reduction of $\mathbf{4}$ to $\mathbf{3}$ switches the substituent from an electron-withdrawing nitro group to an electron-donating amino group and causes a significant red shift. The spectra of 1a, 2a and 3 are dominated by very broad absorption bands that cover a large part of the visible spectrum $(350-750 \mathrm{~nm})$. These broad bands are representative of perylene diimide (dianhydride) derivatives $N$-substituted at the bay-core positions, due to charge transfer absorption [53]. The longest wavelength absorption band of 1-(N,N-dihexylamino)perylene diimide (2a: $610 \mathrm{~nm})$ is red-shifted relative to that of 1-aminoperylene diimide $(3: 578 \mathrm{~nm})$, but it is blue-shifted relative to that of 1-(N,N-dihexylamino)perylene tetracarboxylic dianhydride (1a: $650 \mathrm{~nm})$. It appears that the inductive effect of the alkyl groups in 1a and 2a causes an additional red shift. Interestingly, the longest wavelength absorption band of $\mathbf{1 a}$ is $40-\mathbf{n m}$ red-shifted relative to that of $\mathbf{2 a}$; the decrease in the energy band gap is attributed to a great decrease in the LUMO energy level (vide infra). 
Figure 3. Normalized absorption spectra of 1a, 2a, 3 and $\mathbf{4}$ in dichloromethane.

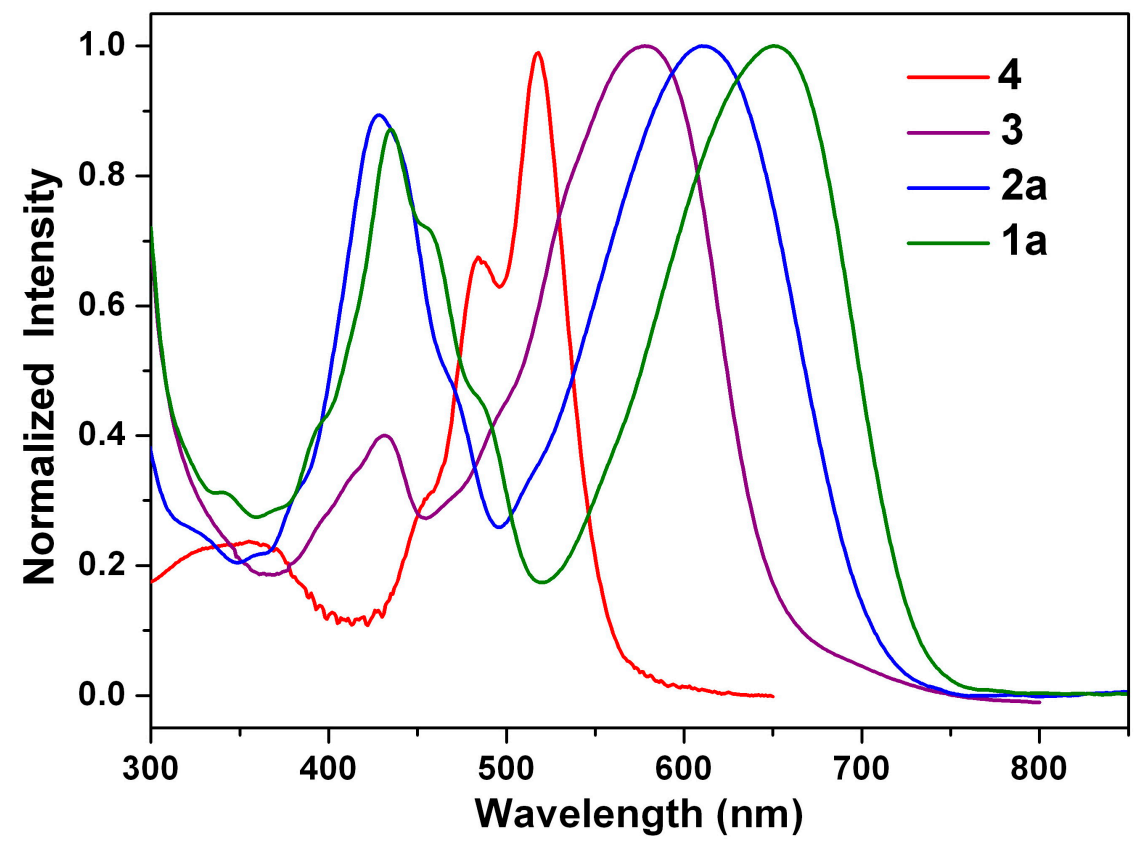

Figure 4 depicts the emission spectra of 1a in solvents of varying polarity, where those of $\mathbf{1 b}$ and $\mathbf{1 c}$ can be found in the Supplementary Materials (Figures S11 and S12). Unlike the small shift in absorption spectra, the fluorescence spectra of 1a-1c are largely red-shifted if there is any increase of the solvent polarity, which indicates strong intramolecular charge transfer characteristics for the excited states of 1a-1c (Table 2). Using the fluorescence solvatochromic shift method [66], we measured the stabilization of the excited-states of $\mathbf{1 a}-\mathbf{1 c}$ and compared these results to those of $\mathbf{2 a - 2 c}$. The change of magnitudes for dipole moments between ground and excited states, i.e., $\Delta \mu=\left|\overrightarrow{\mu_{e}}-\overrightarrow{\mu_{s}}\right|$, can be estimated by the Lippert-Mataga Equation (1) and expressed as:

$$
\bar{v}_{a}-\bar{v}_{f}=\frac{2}{h c}\left(\mu_{e}-\mu_{g}\right)^{2} a_{0}^{-3} \Delta f+\text { const }
$$

where $h$ is the Planck constant, $c$ is the speed of light, $a_{0}$ denotes the cavity radius in which the solute resides, $\bar{v}_{a}-\bar{v}_{f}$ is the Stokes shift of the absorption and emission peak maximum, and $\Delta f$ is the orientation polarizability as shown in Equation (2).

$$
\Delta f=f(\varepsilon)-f\left(n^{2}\right)=\frac{\varepsilon-1}{2 \varepsilon+1}-\frac{n^{2}-1}{2 n^{2}+1}
$$

The plot of the Stokes shift $\bar{v}_{a}-\bar{v}_{f}$ as a function of $\Delta f$ is sufficiently linear for 1a-1c (Figure 5). Accordingly, $\Delta \mu=\left|\overrightarrow{\mu_{e}}-\vec{\mu}_{s}\right|$ values can be calculated as $9.5 \mathrm{D}, 11.9 \mathrm{D}$ and 13.0 D for 1a-1c. These values indicate that dialkylamino-substituted PTCDs (1a-1c) have slightly larger dipole moment changes than those of corresponding dialkylamino-substituted PDIs $(9.0$ D, 11.7 D and 12.8 D for $\mathbf{2 a}-\mathbf{2 c})$. 
Table 2. Summary of optical absorption and emission properties of $\mathbf{1 a}-\mathbf{1 c}$ in various solvents.

\begin{tabular}{ccccc}
\hline $\mathbf{1 a} / \mathbf{1 b} / \mathbf{1 c}$ & $\boldsymbol{\lambda}_{\text {abs }}(\mathbf{n m})^{\mathbf{a}}$ & $\boldsymbol{\lambda}_{\text {em }}(\mathbf{n m})^{\mathbf{a}}$ & Stokes Shift $(\mathbf{n m})^{\boldsymbol{\Phi}^{\mathbf{b}} \times \mathbf{1 0}^{\mathbf{3}}}$ \\
\hline cyclohexane & $623 / 624 / 624$ & $678 / 677 / 679$ & $55 / 53 / 55$ & $1.21 / 1.93 / 7.83$ \\
toluene & $626 / 627 / 627$ & $686 / 686 / 687$ & $60 / 59 / 60$ & $1.01 / 1.15 / 1.38$ \\
diethyl ether & $624 / 626 / 625$ & $708 / 709 / 708$ & $84 / 83 / 83$ & $1.03 / 1.19 / 1.70$ \\
ethyl acetate & $636 / 637 / 637$ & $727 / 726 / 727$ & $91 / 89 / 90$ & $0.90 / 0.81 / 0.96$ \\
tetrahydrofuran & $638 / 639 / 639$ & $731 / 732 / 731$ & $93 / 93 / 92$ & $0.48 / 0.55 / 0.62$ \\
dichloromethane & $640 / 640 / 639$ & $734 / 735 / 735$ & $94 / 95 / 96$ & $0.29 / 0.39 / 0.59$ \\
acetonitrile & $641 / 641 / 642$ & $745 / 745 / 743$ & $104 / 104 / 101$ & $0.16 / 0.24 / 0.33$ \\
\hline
\end{tabular}

${ }^{\text {a }}$ Measured at $2 \times 10^{-5} \mathrm{M} ;{ }^{\mathrm{b}}$ determined with $N, N^{\prime}$-dioctyl-3,4,9,10-perylenedicarboximide as the reference [31].

Figure 4. Normalized emission spectra of $\mathbf{1 a}$ in various solvents.

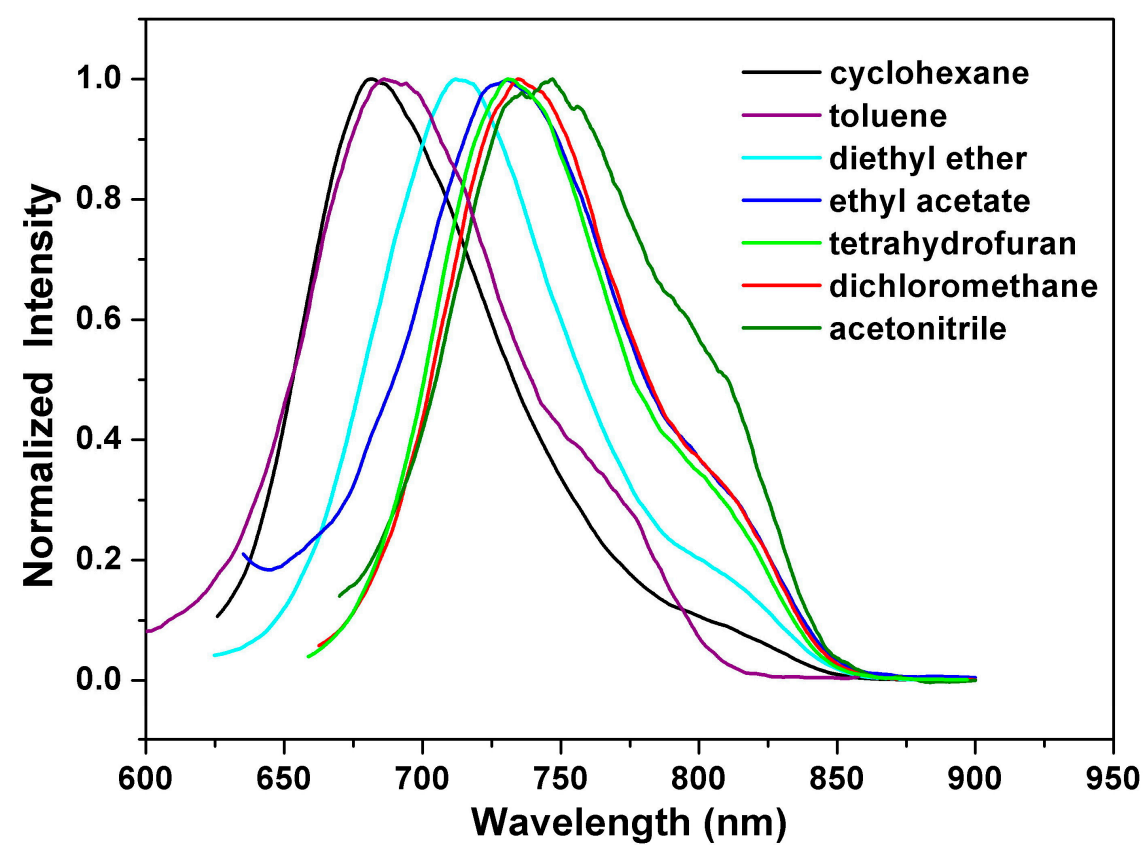

\subsection{Electrochemical Properties}

Figure 6 shows the cyclic voltammograms of 1a and 2a. Both undergo two quasi-reversible one-electron oxidations and two quasi-reversible one-electron reductions in dichloromethane at modest potentials. One can clearly see that both the first oxidation and the first reduction potentials of 1a are larger than those of $\mathbf{2 a}$; this can be explained by the fact that the anhydride group is a stronger electron-withdrawing group than the imide group. Table 3 summarizes the redox potentials and the HOMO and LUMO energy levels estimated from cyclic voltammetry (CV) for 1a-1c and 2a-2c. The HOMO/LUMO energy levels of $\mathbf{1 a}, \mathbf{1 b}, \mathbf{1 c}, \mathbf{2 a}, \mathbf{2 b}$ and $\mathbf{2 c}$ are estimated to be $-5.67 /-3.68,-5.65 /-3.67,-5.66 /-3.69$, $-5.46 /-3.35,-5.47 /-3.36$ and $-5.45 /-3.34 \mathrm{eV}$, respectively. The HOMO-LUMO energy gaps of 1a-1c are found to be virtually the same, which indicates that different $\mathrm{N}$-alkyl chain lengths do not significantly affect the band gap energies. 
Figure 5. Lippert-Mataga plots for 1a (red line and red symbols), $1 \mathbf{b}$ (green line and green symbols) and 1c (blue line and blue symbols). The solvents from left to right are (1) cyclohexane, (2) toluene, (3) diethyl ether, (4) ethyl acetate, (5) tetrahydrofuran, (6) dichloromethane and (7) acetonitrile.

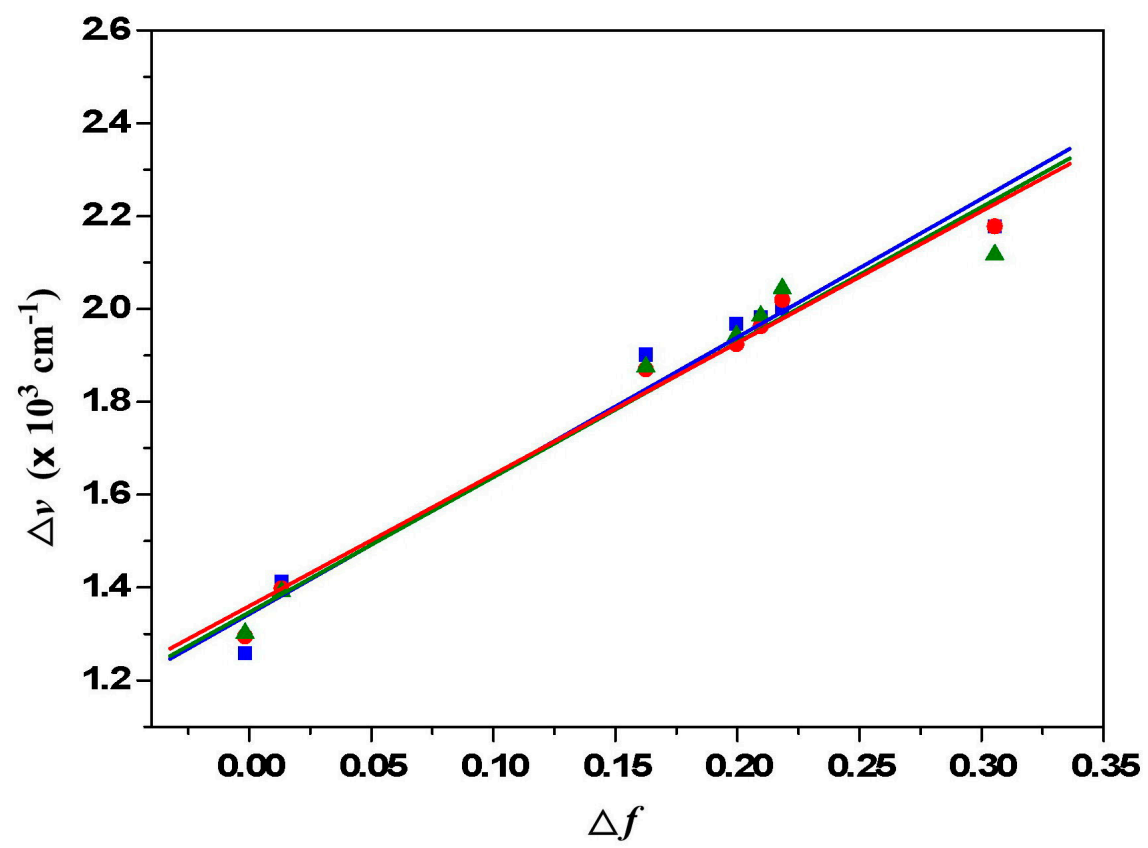

Figure 6. The cyclic voltammograms of 1 a (green line) and 2a (blue line) measured in dichloromethane solution with ferrocenium/ferrocene as an internal standard, at $200 \mathrm{mV} / \mathrm{s}$.

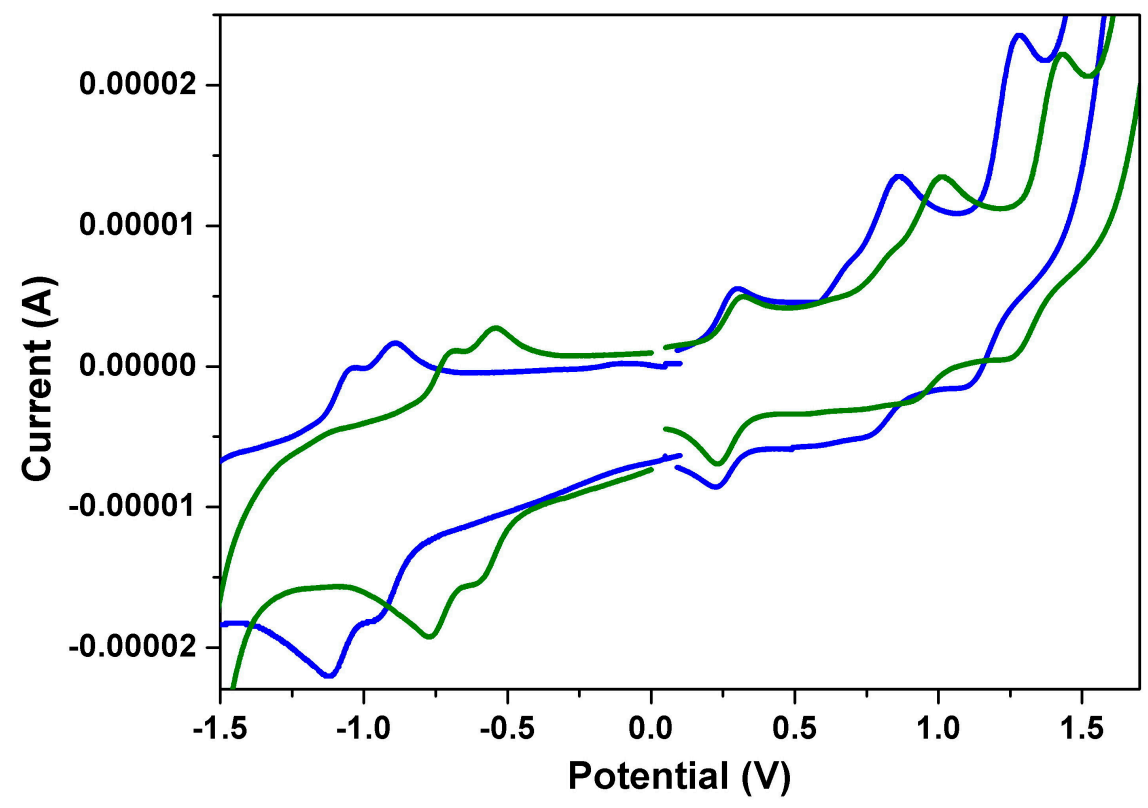


Table 3. Summary of half-wave redox potentials, HOMO and LUMO energy levels for $\mathbf{1 a}-\mathbf{1 c}$ and $\mathbf{2 a}-\mathbf{2 c}$.

\begin{tabular}{ccccccc}
\hline Compound & $\boldsymbol{E}^{+}{ }_{\mathbf{1} / \mathbf{2}}{ }^{\mathbf{a}}$ & $\boldsymbol{E}^{2+}{ }_{\mathbf{1 / 2}}{ }^{\mathbf{a}}$ & $\boldsymbol{E}^{-} \mathbf{1 / 2}^{\mathbf{a}}$ & $\boldsymbol{E}^{\mathbf{2 -}}{ }_{\mathbf{1} / \mathbf{2}}{ }^{\mathbf{a}}$ & $\mathbf{H O M O}^{\mathbf{b}}$ & $\mathbf{L U M O}^{\mathbf{b}}$ \\
\hline $\mathbf{1 a}$ & 1.05 & 1.32 & -0.65 & -0.79 & -5.67 & -3.68 \\
$\mathbf{1 b}$ & 1.03 & 1.31 & -0.66 & -0.80 & -5.65 & -3.67 \\
$\mathbf{1 c}$ & 1.04 & 1.30 & -0.64 & -0.78 & -5.66 & -3.69 \\
$\mathbf{2 a}$ & 0.84 & 1.11 & -0.97 & -1.09 & -5.46 & -3.35 \\
$\mathbf{2 b}$ & 0.85 & 1.13 & -0.95 & -1.10 & -5.47 & -3.36 \\
$\mathbf{2 c}$ & 0.83 & 1.12 & -0.96 & -1.08 & -5.45 & -3.34 \\
\hline
\end{tabular}

${ }^{\text {a }}$ Measured in a solution of $0.1 \mathrm{M}$ tetrabutylammonium hexafluorophosphate (TBAPF 6 ) in dichloromethane versus saturated calomel electrode (in $\mathrm{V}){ }^{\mathrm{b}}$ calculated from $E_{\mathrm{HOMO}}=-4.88-\left(E_{\mathrm{oxd}}-E_{\mathrm{Fc} / \mathrm{Fc}}\right), E_{\mathrm{LUMO}}=E_{\mathrm{HOMO}}+E_{\mathrm{g}}$.

\subsection{Quantum Chemistry Computation}

To gain deeper insight into the molecular structures and electronic properties of $\mathbf{1 a - 1 c}$ and $\mathbf{2 a - 2 c}$, quantum chemical calculations were performed using the density functional theory (DFT) at the B3LYP/6-31G** level. Figure 7 depicts the highest occupied molecular orbitals (HOMOs) and the lowest unoccupied molecular orbitals (LUMOs) of 1a and 2a. The HOMO of 1a (2a) is delocalized mainly on the amino group and the perylene core, while the LUMO is extended from the central perylene core to the dianhydride (diimide) groups. The calculated and experimental parameters for 1a-1c and 2a-2c are summarized in Table 4. It is apparent that both the HOMO and LUMO energy levels of $\mathbf{1 a}-\mathbf{1 c}$ are lower than those of $\mathbf{2 a - 2} \mathbf{c}$ and are in good agreement with the experimental data.

DFT calculations also show that the ground-state geometries of the perylene core have different core twist angles (Figure 8), i.e., approximate dihedral angles between the two naphthalene subunits attached to the central benzene ring; these are $\sim 8.57^{\circ}$ and $\sim 12.42^{\circ}$ for $\mathbf{1 a}, \sim 8.59^{\circ}$ and $\sim 12.45^{\circ}$ for $\mathbf{1 b}$, $\sim 8.61^{\circ}$ and $\sim 12.44^{\circ}$ for $1 \mathbf{c}, \sim 9.40^{\circ}$ and $\sim 13.43^{\circ}$ for $\mathbf{2 a}, \sim 9.42^{\circ}$ and $\sim 13.45^{\circ}$ for $\mathbf{2 b}$ and $\sim 9.45^{\circ}$ and $\sim 13.49^{\circ}$ for $2 \mathrm{c}$ (Table 4 ); and all are larger than those of $\mathbf{5}\left(\sim 0.00^{\circ}\right)$. As a whole, the core twist angles of dialkylamino-substituted PTCDs $(\mathbf{1 a - 1 c})$ are slightly smaller than those of corresponding PDIs (2a-2c).

Table 4. Calculated and experimental parameters for $\mathbf{1 a}-\mathbf{1 c}$ and $\mathbf{2 a - 2 c}$.

\begin{tabular}{cccccccc}
\hline Compound & HOMO $^{\mathbf{a}}$ & LUMO $^{\mathbf{a}}$ & $\boldsymbol{E}_{\mathbf{g}}{ }^{\mathbf{a}}$ & $\boldsymbol{E}_{\mathrm{g}}{ }^{\mathbf{b}}$ & $\boldsymbol{\mu}_{\mathrm{g}}{ }^{\mathbf{c}}$ & $\boldsymbol{\mu}_{\mathrm{e}}{ }^{\mathbf{d}}$ & Twisting Angle ( $\left.^{\circ}\right)$ \\
\hline $\mathbf{1 a}$ & -5.81 & -3.64 & 2.17 & 1.99 & 4.1 & 13.6 & $8.57,12.42$ \\
$\mathbf{1 b}$ & -5.80 & -3.64 & 2.16 & 1.98 & 4.3 & 16.2 & $8.59,12.45$ \\
$\mathbf{1 c}$ & -5.80 & -3.64 & 2.16 & 1.97 & 4.6 & 17.6 & $8.61,12.47$ \\
$\mathbf{2 a}$ & -5.48 & -3.19 & 2.29 & 2.11 & 3.5 & 12.5 & $9.40,13.43$ \\
$\mathbf{2 b}$ & -5.48 & -3.19 & 2.29 & 2.11 & 3.6 & 15.3 & $9.42,13.45$ \\
$\mathbf{2 c}$ & -5.47 & -3.19 & 2.28 & 2.11 & 3.8 & 16.6 & $9.45,13.49$ \\
\hline
\end{tabular}

${ }^{\mathrm{a}}$ Calculated by DFT/B3LYP (in eV); ${ }^{\mathrm{b}}$ at absorption maxima $\left(E_{\mathrm{g}}=1240 / \lambda_{\max }\right.$, in eV); ${ }^{\mathrm{c}}$ ground-state dipole moment (calculated by DFT/B3LYP, in Debye); ${ }^{\mathrm{d}}$ excited-state dipole moment (in Debye). 
Figure 7. Computed frontier orbitals of 1a and 2a. The upper graphs are the LUMOs, and the lower ones are the HOMOs.

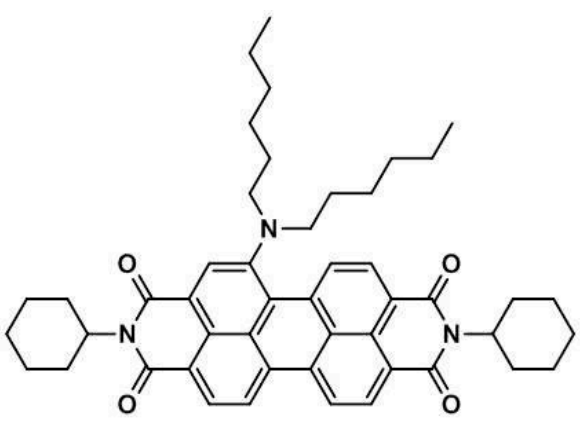

$2 a$
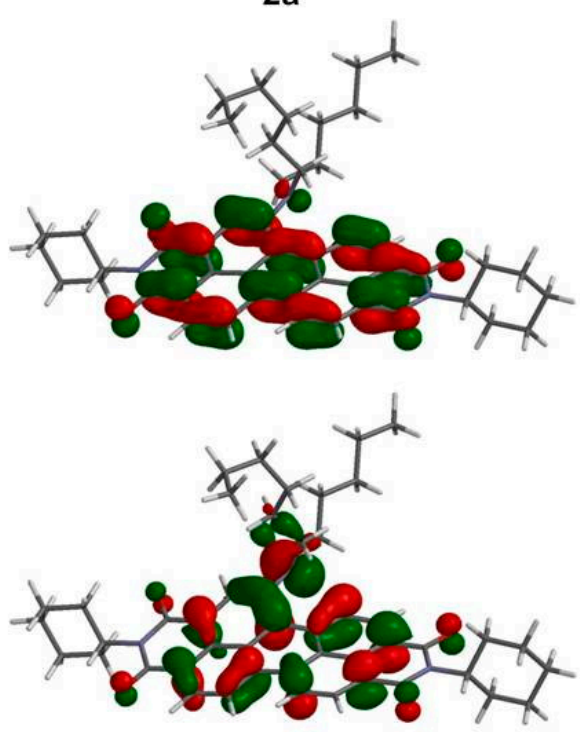

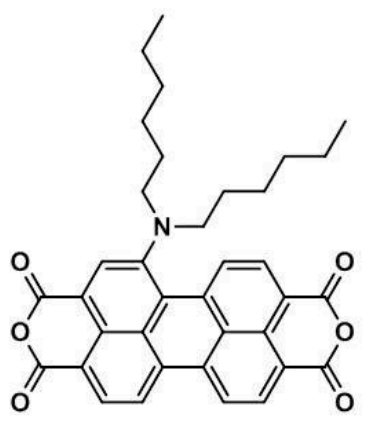

1a
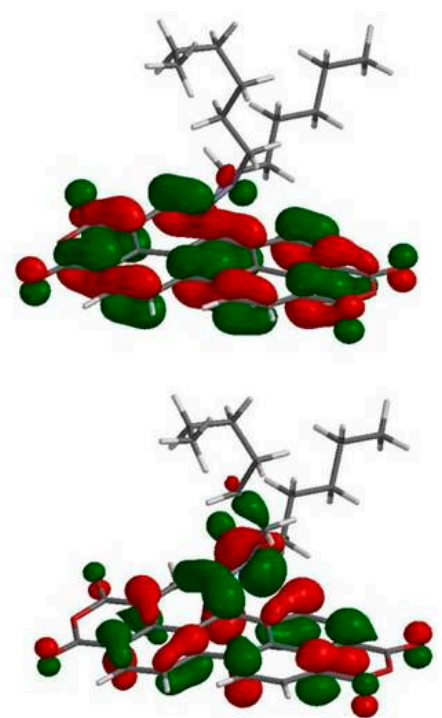

Figure 8. DFT (B3LYP/6-31G**) geometry-optimized structures of 1a (right) and 2a (left) shown with the view along the long perylene axis. For computational purposes, methyl groups replace the cyclohexyl groups at the imide positions.
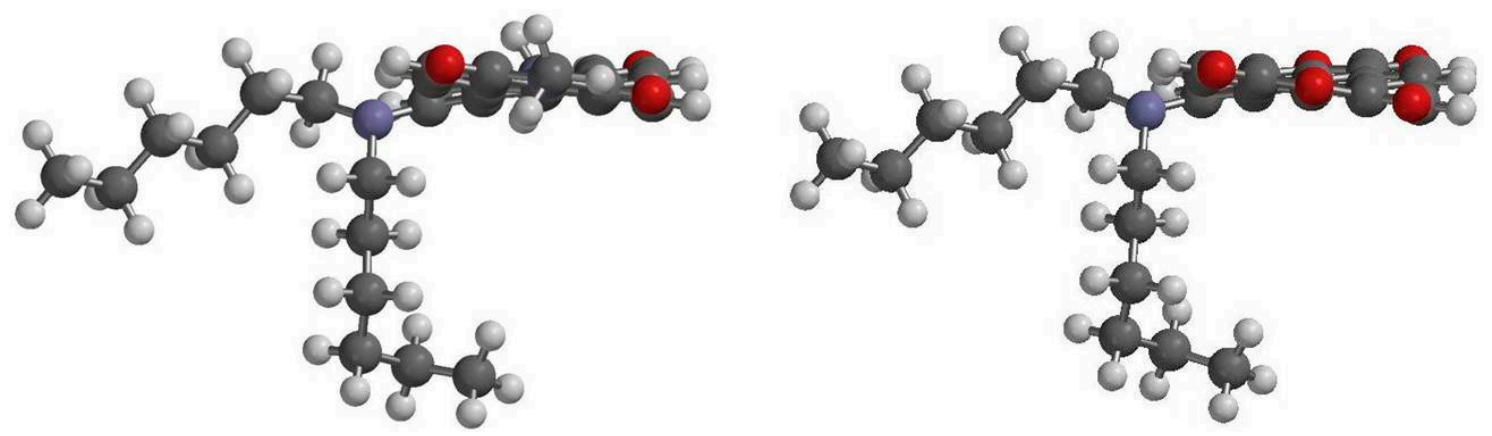

\subsection{Stacking Behaviors of Dyes in Solution and Solid State}

The stacking behaviors of $\mathbf{1 a - 1 c}$ and $\mathbf{3}$ in ethyl acetate were investigated by concentration-dependent UV-Vis measurements (from $10^{-4}$ to $10^{-6} \mathrm{M}$ ). The absorption spectra of $\mathbf{1 a}$ at different concentrations in ethyl acetate are shown in Figure 9; the absorption spectra of 1b, 1c and $\mathbf{3}$ at different concentrations in ethyl acetate are shown in the Supplementary Materials (Figures S13-S15). At high concentrations, a clear red shift was observed for 1-aminoperylene bisimide 3, indicating the formation of J-type aggregates [51]. 
However, compounds 1a-1c show no significant red shift at high concentrations of ethyl acetate, which can be explained by the fact that the long alkyl side chains of $\mathbf{1 a}-\mathbf{1} \mathbf{c}$ decrease the $\pi-\pi$ interactions.

Figure 10 shows the absorption spectra recorded for the thin drop-cast films of $\mathbf{1 a}-\mathbf{1 c}$. The shapes of the absorption spectra of 1a-1c in the solid state and in solution show significant differences, in view of the wavelength range and peak positions. The absorption spectra of all of the drop-cast film chromophores were broadened, as well as red-shifted compared to their respective spectra in cyclohexane solution, which indicates aggregation. This spectral change can be mainly attributed to intermolecular $\pi-\pi$ interactions in the solid state [67].

Figure 9. Normalized absorption spectra of 1a at different concentrations in ethyl acetate.

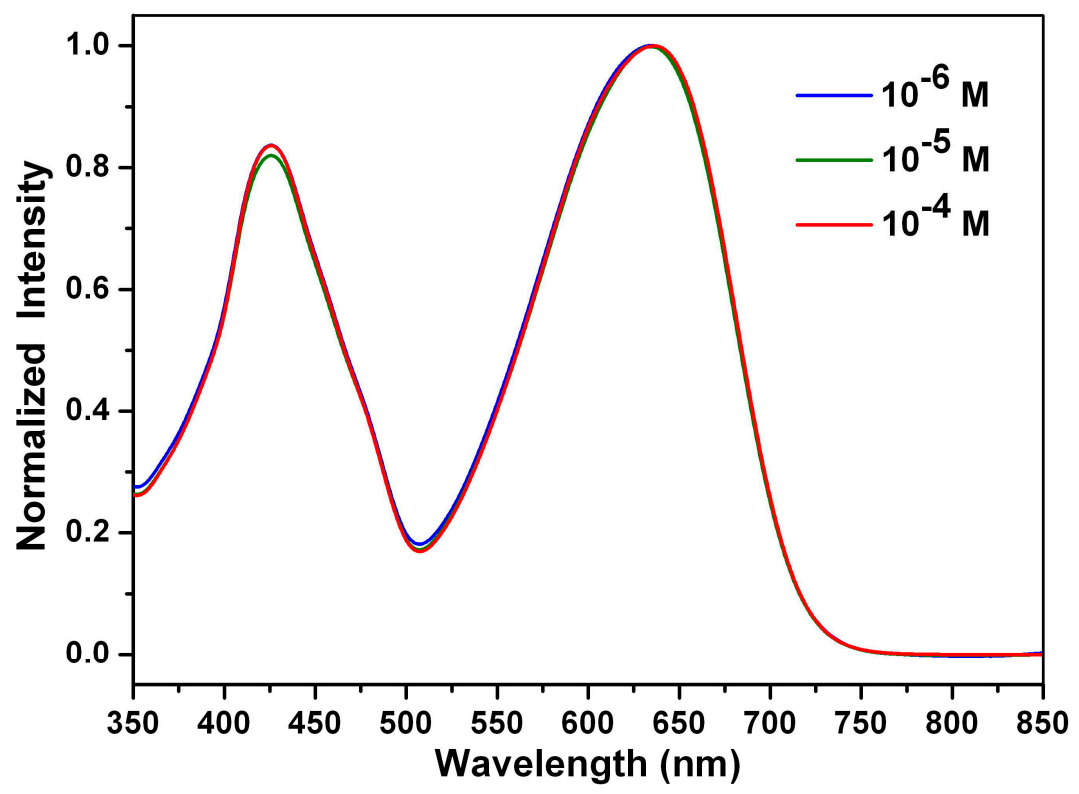

Figure 10. Normalized absorption spectra of 1a-1c in cyclohexane solution (dashed line) and in neat film (solid line).

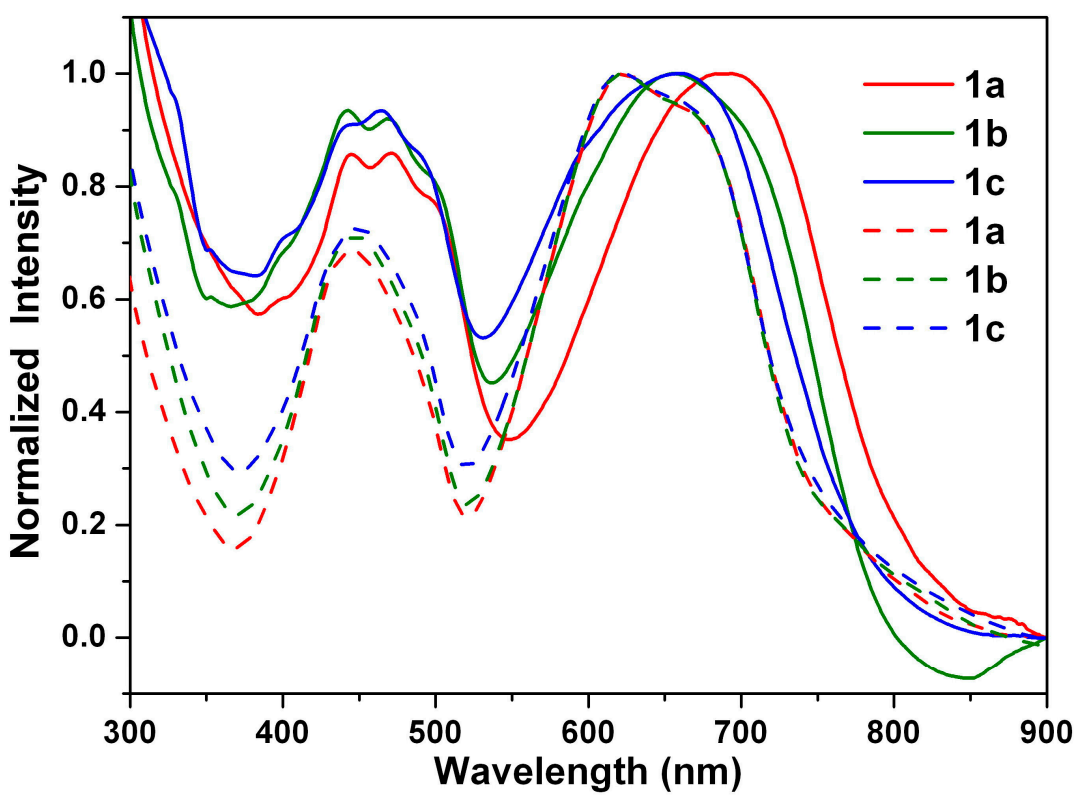




\section{Experimental Section}

\subsection{General}

The starting materials, such as perylene-3,4,9,10-tetracarboxylic dianhydride, acetic acid, cyclohexylamine, cerium(IV) ammonium nitrate (CAN), 1-methyl-2-pyrrolidinone (NMP), tetrahydrofuran (THF), tin (II) chloride dihydrate $\left(\mathrm{SnCl}_{2} \cdot 2 \mathrm{H}_{2} \mathrm{O}\right), \mathrm{KOH}$ and 2-propanol, were purchased from Merck (Whitehouse Station, NJ, USA), ACROS (Pittsburgh, PA, USA) and Sigma-Aldrich (St. Louis, MO, USA). Solvents were distilled freshly according to the standard procedure. Column chromatography was performed using silica gel Merck Kieselgel si 60 (40-63 mesh). ${ }^{1} \mathrm{H}$ or ${ }^{13} \mathrm{C}$ NMR spectra were recorded in $\mathrm{CDCl}_{3}$ on a Bruker 400 or $500 \mathrm{MHz}$ instrument (Palo Alto, CA, USA). Mass spectra were recorded on a VG70-250S mass spectrometer (Tokyo, Japan). The absorption and emission spectra were measured using a Jasco V-570 UV-Vis spectrophotometer (Tokyo, Japan) and a Hitachi F-7000 fluorescence spectrophotometer (Tokyo, Japan), respectively. The Gaussian 03 program (Pittsburgh, PA, USA) was used to perform the $a b$ initio calculation on the molecular structure. Geometry optimizations for Compounds 1a-1c and 2a-2c were carried out with the $6-31 \mathrm{G}^{* *}$ basis set to the B3LYP functional. Vibrational frequencies were also performed to check whether the optimized geometrical structures for all compounds were at energy minima, transition states or higher order saddle points.

\subsection{Synthesis}

\subsubsection{Synthesis of 1-Nitroperylene Diimide (4)}

Compound 5 (1.8 mmol), cerium (IV) ammonium nitrate (1.2 g, $2.2 \mathrm{mmol})$, nitric acid (2.0 g, $31.7 \mathrm{mmol})$ and dichloromethane $(150 \mathrm{~mL})$ were stirred at $25{ }^{\circ} \mathrm{C}$ under $\mathrm{N}_{2}$ for $2 \mathrm{~h}$. The mixture was neutralized with $10 \% \mathrm{KOH}$ and extracted with $\mathrm{CH}_{2} \mathrm{Cl}_{2}$. After the solvent was removed, the crude product was purified by silica gel column chromatography with eluent $\mathrm{CH}_{2} \mathrm{Cl}_{2}$ to afford 4 in a $95 \%$ yield. Characterization data: ${ }^{1} \mathrm{H}$ NMR $\left(500 \mathrm{MHz}, \mathrm{CDCl}_{3}\right) \delta 8.74(1 \mathrm{H}, \mathrm{d}, J=7.6 \mathrm{~Hz}), 8.62-8.69(4 \mathrm{H}, \mathrm{m})$, $8.55(1 \mathrm{H}, \mathrm{d}, J=8.5 \mathrm{~Hz}), 8.18(1 \mathrm{H}, \mathrm{d}, J=7.6 \mathrm{~Hz}), 5.00(2 \mathrm{H}, \mathrm{m}), 2.54(4 \mathrm{H}, \mathrm{m}), 1.91$ (4H, m), $1.76(6 \mathrm{H}, \mathrm{m})$, $1.47(4 \mathrm{H}, \mathrm{m}), 1.34(2 \mathrm{H}, \mathrm{m})$; MS (FAB): $m / z$ (relative intensity) $600\left[\mathrm{M}+\mathrm{H}^{+}, 100\right]$; HRMS calcd. for $\mathrm{C}_{36} \mathrm{H}_{30} \mathrm{O}_{6} \mathrm{~N}_{3} 600.2135$, found 600.2141 .

\subsubsection{Synthesis of 1-Aminoperylene Diimide (3)}

Tin chloride dihydrate $(2.5 \mathrm{~g}, 10.2 \mathrm{mmol})$ and $4(1.0 \mathrm{~g}, 1.7 \mathrm{mmol})$ were suspended in THF $(50 \mathrm{~mL})$ and stirred $20 \mathrm{~min}$. The solvent was refluxed at $80{ }^{\circ} \mathrm{C}$ with stirring for $2 \mathrm{~h}$. THF was removed at the rotary evaporator, and the residue was dissolved in ethyl acetate and washed with $10 \%$ sodium hydrate solution and brine. The organic layer was dried over anhydrous $\mathrm{MgSO}_{4}$, and the filtrate was concentrated under reduced pressure. The crude product was purified by silica gel column chromatography with eluent ethyl acetate $/ n$-hexane $(2 / 3)$ to afford 3 in an $80 \%$ yield. Characterization data: 3: ${ }^{1} \mathrm{H}$ NMR $\left(400 \mathrm{MHz}, \mathrm{CDCl}_{3}\right) \delta 8.62(1 \mathrm{H}, \mathrm{d}, J=8.0 \mathrm{~Hz}), 8.45(1 \mathrm{H}, \mathrm{d}, J=7.6 \mathrm{~Hz}), 8.38(1 \mathrm{H}, \mathrm{d}, J=8.0 \mathrm{~Hz})$, $8.25(1 \mathrm{H}, \mathrm{d}, J=7.6 \mathrm{~Hz}), 8.18(1 \mathrm{H}, \mathrm{d}, J=8.0 \mathrm{~Hz}), 8.10(1 \mathrm{H}, \mathrm{d}, J=8.0 \mathrm{~Hz}), 7.98(1 \mathrm{H}, \mathrm{s}), 5.03(2 \mathrm{H}, \mathrm{s})$, 
$4.99(2 \mathrm{H}, \mathrm{m}), 2.55(4 \mathrm{H}, \mathrm{m}), 1.91(4 \mathrm{H}, \mathrm{m}), 1.74(6 \mathrm{H}, \mathrm{m}), 1.46-1.40(6 \mathrm{H}, \mathrm{m}) ; \mathrm{MS}(\mathrm{FAB}): \mathrm{m} / z$ (relative intensity) $570\left[\mathrm{M}+\mathrm{H}^{+}, 100\right]$; HRMS calcd. for $\mathrm{C}_{36} \mathrm{H}_{32} \mathrm{O}_{4} \mathrm{~N}_{3} 570.2393$, found 570.2396.

\subsubsection{General Procedure for Alkylation (2a-2c)}

A mixture of a solution of 3 (400 mg, $0.70 \mathrm{mmol})$, sodium hydride $(97 \%, 100 \mathrm{mg}, 4.00 \mathrm{mmol})$ and dry THF $(50 \mathrm{~mL})$ was stirred at $0{ }^{\circ} \mathrm{C}$ under $\mathrm{N}_{2}$ for $30 \mathrm{~min}$. Alkyl iodide $(1.60 \mathrm{mmol})$ was then added, and the resulting mixture was stirred for $2 \mathrm{~h}$. The resulting mixture was diluted with $15 \mathrm{~mL}$ of water and extracted with $\mathrm{CH}_{2} \mathrm{Cl}_{2}$. The crude product was purified by silica gel column chromatography with eluent ethyl acetate/ $n$-hexane $(1 / 2)$ to afford $\mathbf{2 a}(\mathbf{2 b}$ or $\mathbf{2 c}$ ) in an $85 \%$ yield. Characterization data: $\mathbf{2 a}$ : ${ }^{1} \mathrm{H}$ NMR (400 MHz, $\left.\mathrm{CDCl}_{3}\right) \delta 9.32(\mathrm{~d}, J=8.0 \mathrm{~Hz}, 1 \mathrm{H}), 8.49-8.53(\mathrm{~m}, 2 \mathrm{H}), 8.48(\mathrm{~s}, 1 \mathrm{H}), 8.31-8.39$ $(\mathrm{m}, 3 \mathrm{H}), 5.02(\mathrm{~m}, 2 \mathrm{H}), 3.40(\mathrm{~m}, 2 \mathrm{H}), 3.06(\mathrm{~m}, 2 \mathrm{H}), 2.55(\mathrm{~m}, 4 \mathrm{H}), 1.90(\mathrm{~m}, 4 \mathrm{H}), 1.62-1.79(\mathrm{~m}, 8 \mathrm{H})$, $1.46(\mathrm{~m}, 4 \mathrm{H}), 1.16-1.30(\mathrm{~m}, 16 \mathrm{H}), 0.77(\mathrm{t}, J=6.4 \mathrm{~Hz}, 6 \mathrm{H}) ;{ }^{13} \mathrm{C} \mathrm{NMR}\left(100 \mathrm{MHz}, \mathrm{CDCl}_{3}\right) \delta 164.07$, $164.06,163.99,163.86,150.56,135.47,134.63,133.53,131.41,130.61,129.11,128.95,128.10$, 126.98, 126.94, 126.93, 124.80, 124.03, 123.44, 123.19, 122.76, 122.11, 121.30, 121.19, 54.04, 53.82, 52.55, 31.44, 29.67, 29.18, 29.11, 27.47, 26.89, 26.59, 25.51, 22.52, 13.89; MS (FAB): $\mathrm{m} / z$ (relative intensity) $738\left[\mathrm{M}+\mathrm{H}^{+}, 100\right]$; HRMS calcd. for $\mathrm{C}_{48} \mathrm{H}_{56} \mathrm{O}_{4} \mathrm{~N}_{3}$ 738.4271, found 738.4277. Selected data for 2b: ${ }^{1} \mathrm{H}$ NMR (400 MHz, $\left.\mathrm{CDCl}_{3}\right) \delta 9.29(\mathrm{~d}, J=8.0 \mathrm{~Hz}, 1 \mathrm{H}), 8.47-8.52(\mathrm{~m}, 2 \mathrm{H}), 8.46(\mathrm{~s}, 1 \mathrm{H})$, 8.29-8.43 (m, 3H), $5.01(\mathrm{~m}, 2 \mathrm{H}), 3.38(\mathrm{~m}, 2 \mathrm{H}), 3.05(\mathrm{~m}, 2 \mathrm{H}), 2.56(\mathrm{~m}, 4 \mathrm{H}), 1.90(\mathrm{~m}, 4 \mathrm{H}), 1.60-1.77$ $(\mathrm{m}, 6 \mathrm{H}), 1.46(\mathrm{~m}, 6 \mathrm{H}), 1.11-1.20(\mathrm{~m}, 40 \mathrm{H}), 0.82(\mathrm{t}, J=6.7 \mathrm{~Hz}, 6 \mathrm{H}) ;{ }^{13} \mathrm{C} \mathrm{NMR}\left(100 \mathrm{MHz}, \mathrm{CDCl}_{3}\right)$ $\delta 164.05,164.03,163.97,163.82,150.56,135.44,134.60,133.49,131.40,130.57,129.09,128.93$, $128.05,126.95,126.91,126.89,124.77,124.01,123.42,123.18,122.75,122.00,121.27,121.14$, 54.04, 53.81, 52.49, 31.86, 29.68, 29.56, 29.50, 29.28, 29.19, 29.11, 27.50, 27.21, 26.60, 25.51, 22.64, 14.07; MS (FAB): $m / z$ (relative intensity) $906\left[\mathrm{M}+\mathrm{H}^{+}, 100\right]$; HRMS calcd. for $\mathrm{C}_{60} \mathrm{H}_{80} \mathrm{O}_{4} \mathrm{~N}_{3} 906.6149$, found 906.6141. Selected data for 2c: ${ }^{1} \mathrm{H}$ NMR (400 $\left.\mathrm{MHz}, \mathrm{CDCl}_{3}\right) \delta 9.37(\mathrm{~d}, J=8.0 \mathrm{~Hz}, 1 \mathrm{H})$, 8.53-8.56 (m, 2H), $8.48(\mathrm{~s}, 1 \mathrm{H}), 8.38-8.43(\mathrm{~m}, 3 \mathrm{H}), 5.03(\mathrm{~m}, 2 \mathrm{H}), 3.44(\mathrm{~m}, 2 \mathrm{H}), 3.07(\mathrm{~m}, 2 \mathrm{H}), 2.56$ $(\mathrm{m}, 4 \mathrm{H}), 1.91(\mathrm{~m}, 4 \mathrm{H}), 1.63-1.73(\mathrm{~m}, 6 \mathrm{H}), 1.47(\mathrm{~m}, 6 \mathrm{H}), 1.12-1.20(\mathrm{~m}, 64 \mathrm{H}), 0.85(\mathrm{t}, J=6.7 \mathrm{~Hz}, 6 \mathrm{H})$; ${ }^{13} \mathrm{C}$ NMR $\left(100 \mathrm{MHz}, \mathrm{CDCl}_{3}\right) \delta 164.15,164.09,164.05,163.88,150.54,135.56,134.75,133.63$, $131.51,130.70,129.19,129.04,128.17,127.03,124.87,124.06,123.50,123.46,123.44,123.22$, 122.82, 122.22, 121.34, 121.23, 54.03, 53.82, 52.61, 31.91, 29.67, 29.64, 29.58, 29.51, 29.34, 29.27, 29.19, 29.12, 27.54, 27.22, 26.59, 25.51, 22.67, 14.09; MS (FAB): $m / z$ (relative intensity) 1074 $\left[\mathrm{M}+\mathrm{H}^{+}, 100\right]$; HRMS calcd. for $\mathrm{C}_{72} \mathrm{H}_{104} \mathrm{O}_{4} \mathrm{~N}_{3}$ 1074.8027, found 1074.8019.

\subsubsection{General Procedure for Saponification (1a-1c)}

2a (2b or 2c, $0.27 \mathrm{mmol})$ was taken in 2-propanol $(30 \mathrm{~mL})$, and subsequently, $\mathrm{KOH}(1.9 \mathrm{~g}$, $33.8 \mathrm{mmol}$ ) was added. The reaction mixture was stirred under $\mathrm{N}_{2}$ at reflux for $4 \mathrm{~h}$. After being cooled to room temperature, the reaction mixture was poured into acetic acid $(50 \mathrm{~mL})$ and stirred overnight. The resulting green precipitate was collected by filtration, washed with water and methanol and dried. The crude product was purified by silica gel column chromatography with eluent $\mathrm{CH}_{2} \mathrm{Cl}_{2}$ to afford 1a (1b or 1c) in a 75\% yield. Characterization data: 1a: ${ }^{1} \mathrm{H}$ NMR $\left(400 \mathrm{MHz}, \mathrm{CDCl}_{3}\right) \delta 9.25(\mathrm{~d}, J=8.0 \mathrm{~Hz}$, $1 \mathrm{H}), 8.60-8.69(\mathrm{~m}, 2 \mathrm{H}), 8.52-8.58(\mathrm{~m}, 4 \mathrm{H}), 3.54(\mathrm{~m}, 2 \mathrm{H}), 3.13(\mathrm{~m}, 2 \mathrm{H}), 1.18-1.63(\mathrm{~m}, 16 \mathrm{H}), 0.87$ (t, $J=6.4 \mathrm{~Hz}, 6 \mathrm{H}$ ); MS (FAB): $m / z$ (relative intensity) $576\left[\mathrm{M}+\mathrm{H}^{+}, 100\right]$; HRMS calcd. for $\mathrm{C}_{36} \mathrm{H}_{34} \mathrm{O}_{6} \mathrm{~N}$ 
576.2386, found 576.2380. Selected data for 1 b: ${ }^{1} \mathrm{H}$ NMR $\left(400 \mathrm{MHz}, \mathrm{CDCl}_{3}\right) \delta 9.22(\mathrm{~d}, J=8.4 \mathrm{~Hz}$, $1 \mathrm{H}), 8.59-8.67(\mathrm{~m}, 2 \mathrm{H}), 8.51-8.57(\mathrm{~m}, 4 \mathrm{H}), 3.54(\mathrm{~m}, 2 \mathrm{H}), 3.13(\mathrm{~m}, 2 \mathrm{H}), 1.13-1.65(\mathrm{~m}, 40 \mathrm{H}), 0.87(\mathrm{t}$, $J=5.2 \mathrm{~Hz}, 6 \mathrm{H}) ;{ }^{13} \mathrm{C}$ NMR $\left(100 \mathrm{MHz}, \mathrm{CDCl}_{3}\right) \delta 164.41,160.25,159.97,159.92,151.13,136.90$, $136.12,134.59,133.83,133.06,131.82,130.00,129.70,128.99,127.69,126.72,124.75,123.73$, $122.09,121.96,119.55,119.22,118.60,116.82,52.84,31.87,29.70,29.56,29.49,29.46,29.29,29.22$, 27.78, 27.12, 22.66, 14.09; MS (FAB): $m / z$ (relative intensity) $744\left[\mathrm{M}+\mathrm{H}^{+}, 100\right]$; HRMS calcd. for $\mathrm{C}_{48} \mathrm{H}_{58} \mathrm{O}_{6} \mathrm{~N}$ 744.4264, found 744.4272. Selected data for 1c: ${ }^{1} \mathrm{H} \mathrm{NMR}\left(400 \mathrm{MHz}, \mathrm{CDCl}_{3}\right) \delta 9.22(\mathrm{~d}$, $J=8.4 \mathrm{~Hz}, 1 \mathrm{H}), 8.62-8.67(\mathrm{~m}, 2 \mathrm{H}), 8.51-8.58(\mathrm{~m}, 4 \mathrm{H}), 3.54(\mathrm{~m}, 2 \mathrm{H}), 3.13(\mathrm{~m}, 2 \mathrm{H}), 1.13-1.68(\mathrm{~m}$, $64 \mathrm{H}), 0.86(\mathrm{t}, J=6.6 \mathrm{~Hz}, 6 \mathrm{H}) ;{ }^{13} \mathrm{C} \mathrm{NMR}\left(100 \mathrm{MHz}, \mathrm{CDCl}_{3}\right) \delta 160.41,160.22,159.95,159.90,151.13$, $136.90,136.12,134.59,133.83,133.05,131.82,129.99,129.70,128.99,127.69,126.72,124.74$, 123.73, 122.09, 121.96, 119.55, 119.22, 118.60, 116.82, 52.84, 31.92, 29.68, 29.57, 29.51, 29.47, 29.35, 29.22, 27.78, 27.13, 22.68, 14.11; MS (FAB): $m / z$ (relative intensity) 912 [M + $\left.\mathrm{H}^{+}, 100\right]$; HRMS calcd. for $\mathrm{C}_{60} \mathrm{H}_{82} \mathrm{O}_{6} \mathrm{~N}$ 912.6142, found 912.6150.

\subsection{Crystal Structural Determination}

A single crystal of $2 \mathbf{a}$ with dimensions of $0.48 \mathrm{~mm} \times 0.12 \mathrm{~mm} \times 0.03 \mathrm{~mm}$ was selected. The lattice constants and diffraction intensities were measured with a Bruker Smart 1000 CCD area detector radiation $(\lambda=0.71073 \AA$ ) at $150(2) \mathrm{K}$. An $\omega$-2 $\theta$ scan mode was used for data collection in the range of $2.22 \leq \theta \leq 26.507$. A total of 32,126 reflections were collected, and 8084 were independent $\left(R_{\text {int }}=0.0626\right)$, of which 4733 were considered to be observed with $I>2 \sigma(I)$ and used in the succeeding refinement. The structure was solved by direct methods with SHELXS-97 [68] and refined on $F^{2}$ by a full-matrix least-squares procedure with Bruker SHELXL-97 packing [69]. All non-hydrogen atoms were refined with anisotropic thermal parameters. The hydrogen atoms refined with riding model position parameters isotropically were located from the difference Fourier map and added theoretically. At the final cycle of refinement, $R=0.0644$ and $w R=0.1601$ $\left(w=1 /\left[\sigma^{2}\left(F_{o}^{2}\right)+(0.0871 P)^{2}+0.8402 P\right]\right.$, where $\left.P=\left(F_{o}^{2}+2 F_{c}^{2}\right) / 3\right), S=1.047,(\Delta / \sigma)_{\max }=0.001$, $(\Delta / \rho)_{\max }=0.337$ and $\left.(\Delta / \rho)_{\min }=-0.375 \mathrm{e} / \AA^{3}\right)$. Crystallographic data for Compound $2 \mathrm{a}$ have been deposited with the Cambridge Crystallographic Data Center as supplementary publication number CCDC 1030664. Copies of this information can be obtained free of charge from the Director, CCDC, 12 Union Road, Cambridge CB2 1EZ, U.K. (Fax: +44 1223336 033; E-mail: deposit@ccdc.cam.ac.uk).

\section{Conclusions}

We have successfully synthesized three monoamino-substituted asymmetrical perylene tetracarboxylic dianhydrides with different $n$-alkyl chain lengths (1a-1c). These molecules show an intense green color in both solution and the solid state and are soluble in most organic solvents and even in nonpolar solvents, such as hexane. They show a unique charge transfer emission in the near-infrared region, of which the peak wavelengths exhibit strong solvatochromism. Upon excitation, they show slightly larger dipole moment changes than those of corresponding perylene diimides $\mathbf{2 a}-\mathbf{2 c}$; the dipole moments of these compounds have been estimated using density functional theory calculations and the Lippert-Mataga equation. Furthermore, they undergo two quasi-reversible 
one-electron oxidations and two quasi-reversible one-electron reductions in dichloromethane at modest potentials. Research on their applications to dye-sensitized solar cells (DSSCs) is currently in progress.

\section{Supplementary Materials}

Supplementary figures can be found at http://www.mdpi.com/1422-0067/15/12/22642/s1.

\section{Acknowledgments}

The project was supported by the Ministry of Science and Technology (MOST 103-2113-M-035-001) in Taiwan. The authors appreciate the Precision Instrument Support Center of Feng Chia University for providing the fabrication and measurement facilities.

\section{Author Contributions}

Kew-Yu Chen supervised the project. Che-Wei Chang measured the data. All authors read and approved the final manuscript.

\section{Conflicts of Interest}

The authors declare no conflict of interest.

\section{References}

1. Choi, J.; Lee, W.; Sakong, C.; Yuk, S.B.; Park, J.S.; Kim, J.P. Facile synthesis and characterization of novel coronene chromophores and their application to LCD color filters. Dyes Pigment. 2012, 94, 34-39.

2. Sakong, C.; Kim, Y.D.; Choi, J.H.; Yoon, C.; Kim, J.P. The synthesis of thermally-stable red dyes for LCD color filters and analysis of their aggregation and spectral properties. Dyes Pigment. 2011, 88, 166-173.

3. Weiss, E.A.; Ahrens, M.J.; Sinks, L.E.; Gusev, A.V.; Ratner, M.A.; Wasielewski, M.R. Making a molecular wire: Charge and spin transport through para-phenylene oligomers. J. Am. Chem. Soc. 2004, 126, 5577-5584.

4. Wilson, T.M.; Tauber, M.J.; Wasielewski, M.R. Toward an $n$-type molecular wire: Electron hopping within linearly linked perylenediimide oligomers. J. Am. Chem. Soc. 2009, 131, 8952-8957.

5. Berberich, M.; Krause, A.M.; Orlandi, M.; Scandola, F.; Würthner, F. Toward fluorescent memories with nondestructive readout: Photoswitching of fluorescence by intramolecular electron transfer in a diaryl ethene-perylene bisimide photochromic system. Angew. Chem. Int. Ed. 2008, 47, 6616-6619.

6. Tan, W.; Li, X.; Zhang, J.; Tian, H. A photochromic diarylethene dyad based on perylene diimide. Dyes Pigment. 2011, 89, 260-265.

7. Jones, B.A.; Ahrens, M.J.; Yoon, M.H.; Facchetti, A.; Marks, T.J.; Wasielewski, M.R. High-mobility air-stable $n$-type semiconductors with processing versatility: Dicyanoperylene-3,4:9,10bis(dicarboximides). Angew. Chem. Int. Ed. 2004, 43, 6363-6366. 
8. Kim, F.S.; Guo, X.; Watson, M.D.; Jenekhe, S.A. High-mobility ambipolar transistors and high-gain inverters from a donor-acceptor copolymer semiconductor. Adv. Mater. 2009, 21, 1-5.

9. Würthner, F.; Stolte, M. Naphthalene and perylene diimides for organic transistors. Chem. Commun. 2011, 47, 5109-5115.

10. Reghu, R.R.; Bisoyi, H.K.; Grazulevicius, J.V.; Anjukandi, P.; Gaidelis, V.; Jankauskas, V. Air stable electron-transporting and ambipolar bay substituted perylene bisimides. J. Mater. Chem. 2011, 21, 7811-7819.

11. Zaumseil, J.; Sirringhaus, H. Electron and ambipolar transport in organic field-effect transistors. Chem. Rev. 2007, 107, 1296-1323.

12. Locklin, J.; Li, D.; Mannsfeld, S.C.B.; Borkent, E.J.; Meng, H.; Advincula, R.; Bao, Z. Organic thin film transistors based on cyclohexyl-substituted organic semiconductors. Chem. Mater. 2005, 17, 3366-3374.

13. Ventura, B.; Langhals, H.; Böck, B.; Flamigni, L. Phosphorescent perylene imides. Chem. Commun. 2012, 48, 4226-4228.

14. Matsui, M.; Wang, M.; Funabiki, K.; Hayakawa, Y.; Kitaguchi, T. Properties of novel perylene-3,4:9,10-tetracarboxidiimide-centred dendrimers and their application as emitters in organic electroluminescence devices. Dyes Pigment. 2007, 74, 169-175.

15. Damaceanu, M.-D.; Constantin, C.-P.; Bruma, N.; Pinteala, M. Tuning of the color of the emitted light from new polyperyleneimides containing oxadiazole and siloxane moieties. Dyes Pigment. 2013, 99, 228-239.

16. Lucenti, E.; Botta, C.; Cariati, E.; Righetto, S.; Scarpellini, M.; Tordin, E.; Ugo, R. New organic-inorganic hybrid materials based on perylene diimide-polyhedral oligomeric silsesquioxane dyes with reduced quenching of the emission in the solid state. Dyes Pigment. 2013, 96, 748-755.

17. Pan, J.; Zhu, W.; Li, S.; Zeng, W.; Cao, Y.; Tian, H. Dendron-functionalized perylene diimides with carrier-transporting ability for red luminescent materials. Polymer 2005, 46, 7658-7669.

18. Li, X.; Sinks, L.E.; Rybtchinski, B.; Wasielewski, M.R. Ultrafast aggregate-to-aggregate energy transfer within self-assembled light-harvesting columns of zinc phthalocyanine tetrakis(perylenediimide). J. Am. Chem. Soc. 2004, 126, 10810-10811.

19. Rybtchinski, B.; Sinks, L.E.; Wasielewski, M.R. Combining light-harvesting and charge separation in a self-assembled artificial photosynthetic system based on perylenediimide chromophores. J. Am. Chem. Soc. 2004, 126, 12268-12269.

20. Kozma, E.; Kotowski, D.; Catellani, M.; Luzzati, S.; Famulari, A.; Bertini, F. Synthesis and characterization of new electron acceptor perylene diimide molecules for photovoltaic applications. Dyes Pigment. 2013, 99, 329-338.

21. Li, J.; Dierschke, F.; Wu, J.; Grimsdale, A.C.; Müllen, K. Poly(2,7-carbazole) and perylene tetracarboxydiimide: A promising donor/acceptor pair for polymer solar cells. J. Mater. Chem. 2006, 16, 96-100.

22. Dinçalp, H.; Aşkar, Z.; Zafer, C.; İçli, S. Effect of side chain substituents on the electron injection abilities of unsymmetrical perylene diimide dyes. Dyes Pigment. 2011, 91, 182-191. 
23. Ramanan, C.; Semigh, A.L.; Anthony, J.E.; Marks, T.J.; Wasielewski, M.R. Competition between singlet fission and charge separation in solution-processed blend films of 6,13-bis(triisopropylsilylethynyl)-pentacene with sterically-encumbered perylene-3,4:9,10bis(dicarboximide)s. J. Am. Chem. Soc. 2012, 134, 386-397.

24. Shibano, Y.; Umeyama, T.; Matano, Y.; Imahori, H. Electron-donating perylene tetracarboxylic acids for dye-sensitized solar cells. Org. Lett. 2007, 9, 1971-1974.

25. Kozma, E.; Catellani, M. Perylene diimides based materials for organic solar cells. Dyes Pigment. 2013, 98, 160-179.

26. Tian, H.; Liu, P.H.; Zhu, W.; Gao, E.; Wu, D.J.; Cai, S. Synthesis of novel multi-chromophoric soluble perylene derivatives and their photosensitizing properties with wide spectral response for $\mathrm{SnO}_{2}$ nanoporous electrode. J. Mater. Chem. 2000, 10, 2708-2715.

27. Choi, H.; Paek, S.; Song, J.; Kim, C.; Cho, N.; Ko, J. Synthesis of annulated thiophene perylene bisimide analogues: Their applications to bulk heterojunction organic solar cells. Chem. Commun. 2011, 47, 5509-5511.

28. Huang, C.; Barlow, S.; Marder, S.R. Perylene-3,4,9,10-tetracarboxylic acid diimides: Synthesis, physical properties, and use in organic electronics. J. Org. Chem. 2011, 76, 2386-2407.

29. Wang, H.Y.; Peng, B.; Wei, W. Solar cells based on perylene bisimide derivatives. Prog. Chem. 2008, 20, 1751-1760.

30. Lu, X.; Guo, Z.; Sun, C.; Tian, H.; Zhu, W. Helical Assembly induced by hydrogen bonding from chiral carboxylic acids based on perylene bisimides. J. Phys. Chem. B 2011, 115, 10871-10876.

31. Würthner, F. Perylene bisimide dyes as versatile building blocks for functional supramolecular architectures. Chem. Commun. 2004, 14, 1564-1579.

32. Wasielewski, M.R. Self-assembly strategies for integrating light harvesting and charge separation in artificial photosynthetic systems. Acc. Chem. Res. 2009, 42, 1910-1921.

33. Kaur, B.; Bhattacharya, S.N.; Henry, D.J. Interpreting the near-infrared reflectance of a series of perylene pigments. Dyes Pigment. 2013, 99, 502-511.

34. Langhals, H.; Kirner, S. Novel fluorescent dyes by the extension of the core of perylenetetracarboxylic bisimides. Eur. J. Org. Chem. 2000, 2, 365-380.

35. Liang, Y.; Wang, H.; Wang, D.; Liu, H.; Feng, S. The synthesis, morphology and liquid-crystalline property of polysiloxane-modified perylene derivative. Dyes Pigment. 2012, 95, 260-267.

36. Kaur, B.; Quazi, N.; Ivanov, I.; Bhattacharya, S.N. Near-infrared reflective properties of perylene derivatives. Dyes Pigment. 2012, 92, 1108-1113.

37. Cui, Y.; Wu, Y.; Liu, Y.; Yang, G.; Liu, L.; Fu, H.; Li, Z.; Wang, S.; Wang, Z.; Chen, Y. PEGylated nanoparticles of diperylene bisimides with high efficiency of ${ }^{1} \mathrm{O}_{2}$ generation. Dyes Pigment. 2013, 97, 129-133.

38. Wang, R.; Shi, Z.; Zhang, C.; Zhang, A.; Chen, J.; Guo, W.; Sun, Z. Facile synthesis and controllable bromination of asymmetrical intermediates of perylene monoanhydride/monoimide diester. Dyes Pigment. 2013, 98, 450-458.

39. Luo, M.-H.; Chen, K.-Y. Asymmetric perylene bisimide dyes with strong solvatofluorism. Dyes Pigment. 2013, 99, 456-464.

40. Kang, H.; Jiang, W.; Wang, Z. Construction of well-defined butadiynylene-linked perylene bisimide arrays via cross-coupling. Dyes Pigment. 2013, 97, 244-249. 
41. Daimon, T.; Nihei, E. Fabrication of a poly(3-octylthiophene-2,5-diyl) electrochemiluminescence device assisted by perylene. Materials 2013, 6, 1704-1717.

42. Sharma, G.D.; Kurchania, R.; Ball, R.J.; Roy, M.S.; Mikroyannidis, J.A. Effect of deoxycholic acid on the performance of liquid electrolyte dye-sensitized solar cells using a perylene monoimide derivative. Int. J. Photoenergy 2012, 2012, doi:10.1155/2012/983081.

43. Tsai, H.Y.; Chang, C.W.; Chen, K.Y. 1,6- and 1,7-Regioisomers of asymmetric and symmetric perylene bisimides: synthesis, characterization and optical properties. Molecules 2014, 19, 327-341.

44. El-Daly, S.A.; Alamry, K.A.; Asiri, A.M.; Hussein, M.A. Spectral characteristics and fluorescence quenching of $N, N^{\prime}$-bis(4-pyridyl)-3,4:9,10-perylenebis(dicarboximide) (BPPD). J. Lumin. 2012, 132, 2747-2752.

45. Tsai, H.Y.; Chen, K.Y. Synthesis and optical properties of novel asymmetric perylene bisimides. J. Lumin. 2014, 149, 103-111.

46. Naveenraj, S.; Raj, M.R. Anandan, S. Binding interaction between serum albumins and perylene-3,4,9,10-tetracarboxylate - A spectroscopic investigation. Dyes Pigment. 2012, 94, 330-337.

47. Zhang, L.; Wang, Y.; Yu, J.; Zhang, G.; Cai, X.; Wu, Y.; Wang, L. A colorimetric and fluorescent sensor based on PBIs for palladium detection. Tetrahedron Lett. 2013, 54, 4019-4022.

48. Boobalan, G.; Imran, P.M.; Ramkumar, S.G.; Nagarajan, S. Fabrication of luminescent perylene bisimide nanorods. J. Lumin. 2014, 146, 387-393.

49. Ma, Y.S.; Wang, C.H.; Zhao, Y.J.; Yu, Y.; Han, C.X.; Qiu, X.J.; Shi, Z. Perylene diimide dyes aggregates: Optical properties and packing behavior in solution and solid state. Supramol. Chem. 2007, 19, 141-149.

50. Rajasingh, P.; Cohen, R.; Shirman, E.; Shimon, L.J.W.; Rybtchinski, B. Selective bromination of perylene diimides under mild conditions. J. Org. Chem. 2007, 72, 5973-5979.

51. Chen, K.Y.; Fang, T.C.; Chang, M.J. Synthesis, photophysical and electrochemical properties of 1-aminoperylene bisimides. Dyes Pigment. 2011, 92, 517-523.

52. Tsai, H.Y.; Chen, K.Y. 1,7-Diaminoperylene bisimides: Synthesis, optical and electrochemical properties. Dyes Pigment. 2013, 96, 319-327.

53. Ahrens, M.J.; Tauber, M.J.; Wasielewski, M.R. Bis(n-octylamino)perylene-3,4:9,10bis(dicarboximide)s and their radical cations: Synthesis, electrochemistry, and ENDOR spectroscopy. J. Org. Chem. 2006, 71, 2107-2114.

54. Wang, H.; Kaiser, T.E.; Uemura, S.; Würthner, F. Perylene bisimide J-aggregates with absorption maxima in the NIR. Chem. Commun. 2008, 10, 1181-1183.

55. Zhao, C.; Zhang, Y.; Li, R.; Li, X.; Jiang, J. Di(alkoxy)- and di(alkylthio)-substituted perylene-3,4;9,10-tetracarboxy diimides with tunable electrochemical and photophysical properties. J. Org. Chem. 2007, 72, 2402-2410.

56. Zhang, X.; Pang, S.; Zhang, Z.; Ding, X.; Zhang, S.; He, S.; Zhan, C. Facile synthesis of 1-bromo-7-alkoxyl perylene diimide dyes: Toward unsymmetrical functionalizations at the 1,7-positions. Tetrahedron Lett. 2012, 53, 1094-1097.

57. Dhokale, B.; Gautam, P.; Misra, R. Donor-acceptor perylenediimide-ferrocene conjugates: Synthesis, photophysical, and electrochemical properties. Tetrahedron Lett. 2012, 53, 2352-2354. 
58. Miasojedovasa, A.; Kazlauskasa, K.; Armonaitea, G.; Sivamuruganb, V.; Valiyaveettilb, S.; Grazuleviciusc, J.V.; Jursenasa, S. Concentration effects on emission of bay-substituted perylene diimide derivatives in a polymer matrix. Dyes Pigment. 2012, 92, 1285-1291.

59. Handa, N.V.; Mendoza, K.D.; Shirtcliff, L.D. Syntheses and properties of 1,6 and 1,7 perylene diimides and tetracarboxylic dianhydrides. Org. Lett. 2011, 13, 4724-4727.

60. Li, Y.; Tan, L.; Wang, Z.; Qian, H.; Shi, Y.; Hu, W. Air-stable n-type semiconductor: Core-perfluoroalkylated perylene bisimides. Org. Lett. 2008, 10, 529-532.

61. Chen, K.Y.; Chow, T.J. 1,7-Dinitroperylene bisimides: Facile synthesis and characterization as n-type organic semiconductors. Tetrahedron Lett. 2010, 51, 5959-5963.

62. Chen, Z.J.; Wang, L.M.; Zou, G.; Zhang, L.; Zhang, G.J.; Cai, X.F.; Teng, M.S. Colorimetric and ratiometric luorescent chemosensor for fluoride ion based on perylene diimide derivatives. Dyes Pigment. 2012, 94, 410-415.

63. Kong, X.; Gao, J.; Ma, T.; Wang, M.; Zhang, A.; Shi, Z.; Wei, Y. Facile synthesis and replacement reactions of mono-substituteded perylene bisimide dyes. Dyes Pigment. 2012, 95, 450-454.

64. Dubey, R.K.; Efimov, A.; Lemmetyinen, H. 1,7- And 1,6-regioisomers of diphenoxy and dipyrrolidinyl substituted perylene diimides: Synthesis, separation, characterization, and comparison of electrochemical and optical properties. Chem. Mater. 2011, 23, 778-788.

65. Würthner, F.; Stepanenko, V.; Chen, Z.; Saha-Möller, C.R.; Kocher, N.; Stalke, D. Preparation and characterization of regioisomerically pure 1,7-disubstituted perylene bisimide dyes. J. Org. Chem. 2004, 69, 7933-7939.

66. Lakowicz, J.R. Principles of Fluorescence Spectroscopy, 2nd ed.; Plenum: Berlin, Germany, 1999.

67. Chen, Z.; Baumeister, U.; Tschierske, C.; Würthner, F. Effect of core twisting on self-assembly and optical properties of perylene bisimide dyes in solution and columnar liquid crystalline phases. Chem. Eur. J. 2007, 13, 450-465.

68. Sheldrick, G.M. SHELXS97, A Program for Automatic Solution of Crystal Structure; University of Göttingen: Wilhelmsplatz, Germany, 1997.

69. Sheldrick, G.M. SHELX97, A Program for Crystal Structure Refinement; University of Göttingen: Wilhelmsplatz, Germany, 1997.

(C) 2014 by the authors; licensee MDPI, Basel, Switzerland. This article is an open access article distributed under the terms and conditions of the Creative Commons Attribution license (http://creativecommons.org/licenses/by/4.0/). 